\title{
(Nad)reprezentacja interesów w procesie kształtowania polityki publicznej na przykładzie obszaru prawno-autorskiego w Polsce ${ }^{2}$
}

\begin{abstract}
Streszczenie
Artykuł poświęcony jest problematyce reprezentacji interesów w procesie kształtowania polityki publicznej. W szczególności podejmuje kwestie związane z zarządzaniem regulacyjnym dotyczącym relacji z grupami interesu oraz strategii stosowanych przez interesariuszy w procesach konsultacyjnych. Ponadto omówiono rolę, jaką grupy interesu odgrywają w polityce publicznej. Analiza dotyczy działań polskich grup interesu w obszarze prawa autorskiego, który zasługuje na uwagę zarówno ze względu na różnorodność aktorów, jak i na asymetrię interesów. Przeprowadzona analiza pozwala stwierdzić, że działania podejmowane przez interesariuszy w zakresie wzmacniania reprezentacji swoich interesów prowadzą do „nadreprezentacji” tych interesów, co - przy braku odpowiednich mechanizmów zarządzania regulacyjnego w zakresie udziału stron w konsultacjach - zwiększa ryzyko wystąpienia zjawiska „zawłaszczania regulacji” przez podmioty. Dane zostały zebrane w ramach monitoringu legislacyjnego projektów ustaw prawno-autorskich procedowanych w latach 2013-2019, a także w toku wywiadów półustrukturyzowanych przeprowadzonych w latach 2015-2018. W celu zilustrowania strategii lobbingowych zastosowano metodę analizy sieci społecznych.
\end{abstract}

Słowa kluczowe: reprezentacja interesów, grupy interesu, lobbing, prawo autorskie, kształtowanie polityki, konsultacje z interesariuszami

Kody klasyfikacji JEL: K29, N44, O52, P14

DOI: $10.33119 / \mathrm{KSzPP} / 2020.2 .6$

1 Uniwersytet im. Adama Mickiewicza w Poznaniu, Wydział Nauk Politycznych i Dziennikarstwa, e-mail: a.vetulani-cegiel@amu.edu.pl, https://orcid.org/0000-0002-4986-6388

2 Badania zostały sfinansowane ze środków Narodowego Centrum Nauki przyznanych w ramach finansowania stażu po uzyskaniu stopnia naukowego doktora na podstawie decyzji numer DEC-2014/12/S/ HS5/00006. 


\title{
(Over)representation of interests in the process of shaping public policies on the example of the legal-copyright area in Poland
}

\begin{abstract}
The article is focused on the issue of the representation of interests in the process of shaping public policies. In particular, it addresses issues related to regulatory management regarding relations with interest groups and strategies used by stakeholders in consultation processes. In addition, we aim to discuss the role that interest groups play in public policies. The analysis concerns the activities of Polish interest groups in the area of copyright, which deserves attention due to the diversity of actors and the asymmetry of interests. The analysis makes it possible to state that the actions taken by stakeholders in strengthening the representation of their interests lead to "overrepresentation" of these interests, which - in the absence of appropriate regulatory management mechanisms for the participation of parties in consultations - increases the risk of the phenomenon of "regulatory capture" by entities. The data was collected as part of the legislative monitoring of drafts of legal-copyright laws proceeded in 2013-2019, as well as semi-structured interviews conducted in 2015-2018. In order to illustrate lobbying strategies, a method of analyzing social networks was used.
\end{abstract}

Keywords: interest representation, interest groups, lobbying, copyright, policymaking, stakeholder consultation

JEL Classification Codes: K29, N44, O52, P14

W niniejszym artykule problematyka reprezentacji interesów w procesie kształtowania polityki publicznej w Polsce została omówiona na przykładzie działań prowadzonych w obszarze prawa autorskiego. Działania związane z reprezentacją interesów grup zainteresowanych jakimś obszarem polityki są ważne, ponieważ, z jednej strony, przyczyniają się do włączania obywateli w procesy legislacyjne, a z drugiej, do ustanawiania wyważonych regulacji prawnych. Podejście ustawodawcy do tej problematyki świadczy też o modelu demokracji, jaki jest realizowany lub do jakiego się dąży w danym momencie.

Obszar prawa autorskiego jako studium przypadku w rozważaniach nad rolą interesariuszy w kształtowaniu polityki i prawa został wybrany nieprzypadkowo. Przez wzgląd na szybki rozwój technologii komunikacyjnych, które stwarzają nowe możliwości w zakresie eksploatacji dzieł przez użytkowników Internetu (w tym również dzieł chronionych prawami autorskimi i pokrewnymi), problematyka prawa autorskiego dotyka coraz większą część społeczeństwa. Ten stan rzeczy pociąga za sobą zmiany w zakresie reprezentacji interesów w postaci zapotrzebowania na reprezentację 
rozproszonych interesów użytkowników. Rozwój technologii internetowych spowodował ponadto pojawienie się nowych kategorii interesariuszy, a mianowicie pośredników i usługodawców internetowych, świadczących usługi w zakresie rozmaitych platform (informacyjnych, agregacji treści, chmur itd.).

Obszar prawa autorskiego wydaje się interesujący również ze względu na specyficzny, tj. asymetryczny układ reprezentacji interesów, a także na wielość i różnorodność występujących aktorów. Obydwa zjawiska wpływają na skuteczność działań lobbingowych podmiotów (zob. analizy na ten temat, np. Dür, Mateo, 2014; Farrand, 2014; Haunss, Kohlmorgen, 2009; Horten, 2013; Littoz-Monnet, 2006; Vetulani-Cęgiel, 2015a; Yu, 2004). Badacze zwracają także uwagę na problem wyważania interesów stron w regulacjach prawnych przez ustawodawcę (Gendreau, 2013; Hilty i in., 2008; Matthews, Žikovská, 2013; Meyer, Vetulani-Cęgiel, 2017). Jak się okazuje, w większości przypadków dochodzi do nieuwzględnienia interesów podmiotów nieuprawnionych z tytułu praw autorskich i pokrewnych, czyli użytkowników chronionych treści.

Zrównoważona reprezentacja interesów w toku procesów konsultacyjnych i legislacyjnych jest jedną z kluczowych kwestii, która powinna być uregulowana w zakresie prowadzenia polityki publicznej. Uważa się, że brak takiej równowagi może prowadzić do „zawłaszczania regulacji” (regulatory capture) przez aktorów reprezentujących partykularne interesy (Rasmussen, 2015: 367). Stosując różne strategie, dążą oni bowiem do wprowadzania korzystnych dla siebie rozwiązań kosztem pozostałych stron. Dodajmy, że ryzyko nieuwzględnienia interesów wszystkich stron zwiększa się w warunkach asymetrycznej reprezentacji interesów lub nieobecności niektórych stron w konsultacjach, a także w sytuacji, gdy niektóre strony mają ułatwiony dostęp do decydentów (przy czym chodzi nie tylko o fizyczny dostęp, ale także o umiejętność wykorzystania właściwego dyskursu - Farrand, 2014; Vetulani-Cęgiel, 2015b).

$\mathrm{W}$ niniejszym artykule proponujemy dwutorowe ujęcie problematyki reprezentacji interesów, a mianowicie uwzględnienie z jednej strony mechanizmów instytucjonalnych, a z drugiej strategii lobbingowych. Jeśli chodzi o te pierwsze, mamy na myśli zarządzanie regulacyjne w odniesieniu do relacji z interesariuszami, a w szczególności procedury konsultacji, które w sposób praktyczny określają możliwości lobbingu, ponieważ strukturyzują dostęp do decydentów. Z kolei uwzględnienie strategii pozwala spojrzeć na kwestię reprezentacji interesów i aktywności zainteresowanych stron. Z ogólnego punktu widzenia można stwierdzić, że badania nad grupami interesu w obszarze prawa autorskiego stają się ważnym przyczynkiem, służącym wyjaśnianiu kwestii ogólniejszych, związanych z życiem społecznym oraz procesami demokratyzacji. Dotyczą ponadto sfery praktyki, gdyż potwierdzają konkretne mankamenty procedur konsultacyjnych w Polsce. 


\section{Uwagi metodologiczne}

W artykule przyjęto neoinstytucjonalną perspektywę badawczą, ponieważ uwzględnia ona zależności między instytucjami a podmiotami. W odmianie historycznej tej perspektywy instytucje określane są jako zespół procedur formalnych i nieformalnych, a także norm oraz konwencji zakorzenionych w strukturze ustroju politycznego (Jasiecki, 2013). Obrana perspektywa jest szczególnie przydatna w badaniach nad reprezentacją interesów, ponieważ pozwala spojrzeć na tę kwestię pod kątem współoddziaływania instytucji oraz aktorów niepaństwowych, jakimi są grupy interesu. O ile ogólny model lobbingu wynika z uwarunkowań ustrojowych, o tyle faktyczna rola interesariuszy w procesach politycznych, a przez to i w demokracji, jest na bieżąco kształtowana przez odpowiednie normy i procedury w ramach zarządzania regulacyjnego (regulatory governance). W szczególności chodzi o rozwiązania rejestrowe oraz procedury konsultacji $\mathrm{z}$ interesariuszami ${ }^{3}$.

$\mathrm{Z}$ uwagi na fakt, iż celem pracy jest omówienie roli, jaką grupy interesu odgrywają $\mathrm{w}$ polityce publicznej, rozważania zawarte w niniejszym artykule skupiają się na stosowanych przez te grupy strategiach oraz na ich implikacjach. Założono, że poprzez odpowiednie zarządzanie partycypacją interesariuszy w procesach konsultacyjnych (i tym samym legislacyjnych) można zapobiegać problemom wynikającym z nierównomiernej reprezentacji interesów stron w sferze publicznej.

Analiza funkcjonujących w Polsce mechanizmów dotyczących reprezentacji interesów ma zwrócić uwagę zarówno na czynniki instytucjonalne, jak i te o charakterze lobbingowym. W przypadku tych pierwszych ma wykazać, że pośród narzędzi służących do zarządzania reprezentacją interesów w toku procesów kształtowania polityki i stanowienia prawa występują procedury konsultacji publicznych. W tym kontekście warto się zastanowić, w jakim zakresie polski ustawodawca reguluje kwestię konsultacji z interesariuszami oraz czy obecne procedury pozwalają na przeciwdziałanie zagrożeniom wynikającym z nierównomiernej reprezentacji interesów. Przyjęto w pracy następującą hipotezę:

H1: Istniejace $w$ Polsce mechanizmy instytucjonalne dotyczace udziatu interesariuszy $w$ procesach konsultacyjnych (i legislacyjnych) nie pozwalaja na zminimalizowanie ryzyka wystapienia zjawiska „zawłaszczania regulacji” przez wplywowe podmioty.

3 Nie są omawiane w niniejszym artykule przepisy dotyczące rejestrowania działalności lobbingowej. Uregulowania w tym zakresie określają zwykle zasady dotyczące wstępu do budynku (przepustki) i akredytacji oraz odnoszą się do kontaktów personalnych. Z kolei procedury konsultacji określają możliwości udziału (a zatem i rolę) interesariuszy w procesie wytyczania polityki i stanowienia prawa (w sposób bardziej całościowy). 
Omawiając mechanizmy lobbingowe, skoncentrowano się na działaniach kolektywnych grup interesu, ponieważ wydaje się, iż należą one do przemyślanych strategii, stosowanych w celu wzmacniania interesów w toku procesów legislacyjnych. W szczególności interesujące jest, jakie strategie stosują strony w celu polepszenia reprezentacji interesów. Przeprowadzone badania pozwalają przyjąć hipotezę:

H2: Podejmowane przez interesariuszy aktywne działania $w$ zakresie wzmacniania reprezentacji swoich interesów prowadza nie tylko do integracji danego środowiska, ale też do „nadreprezentacji” określonych interesów.

W celu weryfikacji powyższych założeń zwrócono uwagę na uwarunkowania systemowe, które determinują model reprezentacji interesów oraz relacje z interesariuszami, a także określają ich rolę w demokracji. W szczególności omówiono uregulowania w zakresie konsultacji publicznych w procesach kształtowania polityki i stanowienia prawa oraz skonfrontowano rozwiązania stosowane w Polsce z rozwiązaniami unijnymi (jako punkt odniesienia). Następnie skoncentrowano się na działaniach podejmowanych przez zainteresowane strony w celu wzmocnienia reprezentacji swoich interesów. Dla zilustrowania strategii interesariuszy wykorzystano metodę analizy sieci społecznych z uwagi na fakt, że pozwala ona w sposób transparentny zwizualizować zależności między podmiotami w ujęciu statycznym (np. dotyczącym członkostwa) i jednocześnie dynamicznym (np. w odniesieniu do uczestnictwa w procesach konsultacyjnych).

Wyniki analiz zostały uzyskane na podstawie danych pochodzących z oficjalnych źródeł, takich jak strony internetowe interesariuszy, strony rządowego procesu legislacji, oraz aktualnej literatury przedmiotu, a także opinii ekspertów monitorujących procesy legislacji w Polsce. Dane szczegółowe na temat procesów konsultacji zostały pozyskane $\mathrm{w}$ ramach monitoringu legislacyjnego ${ }^{4} \mathrm{i}$ dotyczyły sześciu procesów legislacyjnych związanych z projektami ustaw w zakresie przepisów prawno-autorskich procedowanych w okresie od 2013 do 2019 roku. W toku tych procesów, na etapie prac rządowych, przeprowadzono pięć otwartych pisemnych konsultacji publicznych oraz jedno publiczne wysłuchanie zorganizowane przez komisję sejmową. Badania objęły wszystkich interesariuszy uczestniczących w ww. konsultacjach. Zebrane dane zostały uzupełnione o informacje pochodzące $\mathrm{z}$ wielu półustrukturyzowanych wywiadów z przedstawicielami grup interesu (branż kreatywnych, organizacji społeczeństwa obywatelskiego) i administracji publicznej. Respondenci reprezentowali grupy najbardziej aktywne w obszarze prawa autorskiego w Polsce. W niniejszym artykule zaobserwowane mechanizmy lobbingowe przedstawiono na przykładzie działań interesariuszy w obrębie branży kreatywnej.

\footnotetext{
4 Badania własne w ramach prac Obywatelskiego Forum Legislacji.
} 


\section{Uwarunkowania instytucjonalno-prawne modelu reprezentacji interesów}

W systemach demokratycznych grupy interesów pełnią trzy funkcje: reprezentacyjną, ekspercką oraz kontrolną. Pierwsza z nich polega na reprezentowaniu określonego środowiska względem decydentów politycznych, stanowiąc ogniwo pośrednie w komunikacji między obywatelami a ustawodawcą. W ten sposób interesariusze artykułują potrzeby swojego środowiska oraz zabiegają o ochronę jego interesów (Antoszewski, 2003; Herbut, 2003). Druga funkcja, ekspercka, związana jest z przekazywaniem wiedzy. Grupy interesu, a zwłaszcza te, które reprezentują wąskie sektory gospodarki, posiadają specjalistyczną wiedzę na temat specyfiki oraz problemów występujących w danej branży, której to wiedzy nie ma ustawodawca. Ich zasadniczą rolą jest zatem dostarczanie ustawodawcy specjalistycznego wkładu merytorycznego (Bouwen, 2002; Gornitzka, Holst, 2015). Trzecią funkcją, jaką grupy interesu pełnią w demokracji, jest funkcja kontrolna. Zazwyczaj chodzi o kontrolę nad demokratycznością procesów stanowienia prawa, jaką sprawują organizacje strażnicze (watchdogi). Jednak już samo uczestnictwo różnych stron w procesach politycznych stanowi krok w kierunku zrównoważonej reprezentacji interesów, ponieważ daje szansę na merytoryczną (i społeczną) kontrolę proponowanych rozwiązań prawnych, a w konsekwencji na wyważone regulacje prawne. Odpowiednia reprezentacja interesów ma zatem fundamentalne znaczenie w procesie kształtowania polityki publicznej.

To, w jaki sposób próbuje się kształtować relacje z interesariuszami, wynika z przesłanek historycznych i ustrojowych, które określają rolę i miejsce interesariuszy w systemie politycznym ${ }^{5}$. Jeśli chodzi o model reprezentacji interesów w Polsce, podaje się, że w znacznej mierze został on ukształtowany przez tradycję korporacjonizmu socjalistycznego (Jasiecki, 2000). Nadal obserwuje się niski poziom zaufania społecznego do władzy oraz niską partycypację polityczną obywateli (Jasiecki, 2015). Lobbing był, i wciąż jest, utożsamiany z powiązaniami personalnymi oraz z naciskami biznesowymi na ustawodawcę, a także z zachowaniami nieetycznymi, a nie z działalnością organizacji grup interesu (stowarzyszeń, zrzeszeń, fundacji) (Jasiecki, 2000; Kopka i in., 2018). Wprowadzane w 2005 roku w Ustawie o działalności lobbingowej (Ust. lobb.,

5 W systemach pluralistycznych (np. w Stanach Zjednoczonych) grupy interesu rywalizują o dostęp do decydentów w warunkach konkurencji, która umożliwia uzyskiwanie dynamicznej równowagi wpływów społecznych w instytucjach władzy, natomiast w systemach o tradycjach korporatywistycznych (państwa europejskie) zinstytucjonalizowane formy dialogu (chodzi o dialog społeczny, czyli trójstronne negocjacje ze związkami zawodowymi i organizacjami pracodawców) zwykle przeważają nad mechanizmami w zakresie rejestracji lobbystów i konsultacji (Jasiecki, 2002: 118). Ciekawym przypadkiem jest system polityczny Unii Europejskiej, który łączy elementy obu modeli. 
2005) regulacje były podyktowane zamiarem zapobiegania zjawiskom o charakterze korupcyjnym (Wiszowaty, 2010), ponieważ chodziło o zapewnienie przejrzystości w relacjach między decydentami a sferą biznesową. W rezultacie zostały ustanowione dwa rejestry osób prowadzących zawodową działalność lobbingową ${ }^{6}$, które nie obejmują jednak interesariuszy instytucjonalnych, tj. organizacji grup interesu, a jedynie osoby fizyczne i podmioty gospodarcze. Ten, między innymi, fakt jest przedmiotem krytyki ze strony reprezentantów doktryny oraz ekspertów (Wiszowaty, 2010: 112; zob. też Ferfecki, 2018).

Jeśli chodzi o konsultacje publiczne z interesariuszami, to funkcjonują w Polsce dwa mechanizmy, a mianowicie instytucja wysłuchania publicznego oraz pisemne konsultacje z interesariuszami ${ }^{7}$. Wysłuchanie zostało wprowadzone w 2005 r. (Ust. lobb., 2005, art. 8, 9) w dwóch odsłonach: parlamentarnej i rządowej. W założeniu wysłuchanie miało być jednym z elementów wprowadzania zasad jawności w działaniach lobbingowych. $Z$ uwagi jednak na fakt, że ten instrument nie jest obowiązkowy, ustawodawca nie wykorzystuje go w sposób regularny (Jasiecki, 2015: 111; Cianciara, 2018: 99). Jeśli zaś chodzi o obowiązek przeprowadzania konsultacji publicznych, wynika on z procedur zawartych w Regulaminie pracy Rady Ministrów (Reg. RM, 2013). Wprowadzenie tego instrumentu było m.in. wynikiem debat dotyczących potrzeby ulepszenia procesów stanowionego prawa, które zostały podjęte podczas Kongresu Wolności w Internecie w 2012 r., zorganizowanego w następstwie protestów przeciwko ACTA (Umowie handlowej dotyczącej zwalczania obrotu towarami podrabianymi, Anti-Counterfeiting Trade Agreement) w związku z postulatami wprowadzenia przejrzystości procesu legislacyjnego (Dür, Mateo, 2014; Meyer, Vetulani-Cęgiel, 2017). Inicjatywy mające na celu polepszenie standardów procesów legislacyjnych podejmowane były wielotorowo i zaowocowały m.in. opracowaniem tzw. Kodeksu Konsultacji (zawierającego „7 zasad konsultacji” określających główne reguły procesu konsultowania aktów prawnych - Wiaderek, 2015) czy też przyjęciem - wzorowanego na unijnej inicjatywie Smart/Better Regulation - rządowego programu „Lepsze regulacje na lata 2012-2015" (Program Lepsze Regulacje 2015, 2013) ${ }^{8}$.

Funkcjonujące w Polsce procedury konsultacji nie są pozbawione mankamentów. Jednym $\mathrm{z}$ nich jest fakt, że mimo publicznego charakteru informacja o otwarciu

\footnotetext{
6 Jeden rejestr jest prowadzony przez Sejm Rzeczypospolitej Polskiej i jeden przez Ministerstwo Spraw Wewnętrznych i Administracji.

7 W Polsce równolegle funkcjonują zinstytucjonalizowane formy konsultacyjne w postaci dialogu społecznego (z udziałem związków zawodowych i pracodawców) oraz dialogu obywatelskiego (z udziałem organizacji pożytku publicznego). W niniejszym opracowaniu skupiamy się na mechanizmach konsultacji publicznych.

8 Wspomniany Kodeks Konsultacji został włączony do programu „Lepsze regulacje na lata 2012-2015” (Wiaderek, 2015).
} 
konsultacji przekazywana jest stronom w formie pisemnej wg rozdzielnika konstruowanego przez ustawodawcę. W połączeniu z niezwykle krótkim terminem konsultacji (21 dni w przypadku projektów ustaw) ten stan rzeczy powoduje ryzyko pominięcia pewnych stron. Innym mankamentem jest obowiązek przeprowadzania konsultacji publicznych jedynie w przypadku pierwszej wersji danego projektu, w dodatku tylko na etapie rządowym prac legislacyjnych. Oznacza to brak podobnego obowiązku, jeśli chodzi o inne (niż rządowe) projekty aktów prawnych. Regulacje w zakresie konsultacji publicznych nie odnoszą się ponadto do kwestii równoważenia reprezentacji interesów. Stosowana obecnie w Polsce praktyka legislacyjna zyskuje niskie oceny ekspertów. Wskazuje się, że ustawodawca nie docenia znaczenia konsultacji publicznych, stosuje tryby odrębne, skraca czas przeznaczony na konsultacje, prowadzi konsultacje pozorne lub prezentuje projekty rządowe jako poselskie (Obywatelskie Forum Legislacji, 2019).

Również na tle rozwiązań unijnych polskie mechanizmy konsultacyjne wykazują liczne deficyty. Obowiązujący w Unii Europejskiej (UE) model m.in. łączy mechanizm rejestrowy z konsultacyjnym (podmioty wpisane do unijnego rejestru służącego przejrzystości otrzymują alerty dotyczące konsultacji w wybranych obszarach) ${ }^{9}$. Komisja Europejska kładzie nacisk na zapewnienie szerokiego dostępu do konsultacji. W tym celu stworzono specjalną platformę internetową, stanowiącą „pojedynczy punkt dostępu” do różnych konsultacji, wprowadzono 12-tygodniowy okres na przesyłanie kontrybucji (co daje stronom czas na odpowiednie ustosunkowanie się do sprawy), a ponadto przewidziano obowiązek tworzenia stron internetowych dedykowanych poszczególnym konsultacjom. W celu uniknięcia ryzyka zawłaszczania regulacji przez wpływowe strony, zwraca się uwagę na kwestię reprezentacji interesów (European Commission, 2015: 73). W tym aspekcie przewiduje się konieczność identyfikacji interesariuszy w prowadzonych konsultacjach, a także zasięganie opinii u różnych podmiotów (w celu uniknięcia konsultowania się stale z tymi samymi stronami). Zaleca się również analizę kontrybucji z uwzględnieniem

\footnotetext{
9 Unijny model reprezentacji interesów został ukształtowany w związku z tzw. deficytem demokracji w UE (Kurczewska, 2008). Włączanie obywateli do procesów decyzyjnych w UE miało zagwarantować społeczne poparcie dla działań na szczeblu unijnym, czyli tzw. demokratyczną legitymizację „na wejściu” do systemu politycznego oraz na „wyjściu” (Scharpf, 1999). Zgodnie z koncepcją demokracji partycypacyjnej uczestnictwo grup interesu w konsultacjach miało zapewnić legitymację „na wejściu” (Saurugger, 2008: 1276). Z kolei mechanizmy demokracji deliberatywnej (wg J. Habermasa), określające udział interesariuszy w debacie publicznej na zasadach równości stron, argumentacji i równowagi interesów, miały zapewnić legitymizację „na wyjściu”, czyli przyczyniać się do polepszenia jakości polityki publicznej (Crespy, 2014). Mimo że niektórzy podają jednak w wątpliwość to, na ile reprezentacja interesów spełnia przesłanki „demokratyczności” oraz czy pozwala ona faktycznie zapobiegać deficytowi demokracji UE (Kohler-Koch, 2010), działania podjęte w zakresie włączania obywateli do procesów decyzyjnych zaowocowały wykształceniem rozwiniętego (wzorcowego) modelu w zakresie zarządzania reprezentacją interesów.
} 
poszczególnych kategorii interesów (szerzej na ten temat: Vetulani-Cęgiel, 2017). Praktyka pokazuje ponadto, że Komisja Europejska wykorzystuje szeroki wachlarz narzędzi konsultacyjnych w toku formułowania swoich polityk (konsultacje publiczne online, publiczne wysłuchania, ankiety, grupy doradcze, konsultacje dwustronne, konferencje, seminaria itd.).

Reasumując, można stwierdzić, iż ustawodawca polski, w przeciwieństwie do unijnego, w niewielkim tylko stopniu dostrzega pozytywną rolę interesariuszy w demokracji, mimo że są oni źródłem wiedzy eksperckiej i branżowej, a ponadto - reprezentując interesy społeczne - pełnią funkcję kontrolną.

\section{Mechanizmy dotyczące reprezentacji interesów w obszarze prawa autorskiego}

\section{Specyfika reprezentacji interesów}

Prawo autorskie dotyczy różnych interesów i obszarów. Po pierwsze, obowiązuje tam, gdzie chodzi o ekonomiczne interesy podmiotów uprawnionych z tytułu praw autorskich i pokrewnych, działających w tzw. branżach kreatywnych, a po drugie, dotyczy interesów użytkowników chronionych treści. Jeśli chodzi o podmioty uprawnione, są nimi osoby wnoszące pierwiastek twórczy do dzieła (twórcy, artyści) lub przyczyniające się do eksploatacji przedmiotów ochrony w sposób finansowy (producenci, wydawcy). Z kolei wśród użytkowników wyróżnia się podmioty instytucjonalne (biblioteki, archiwa) oraz tzw. użytkowników końcowych, czyli osoby fizyczne, internautów itp.

W większości przypadków podmioty uprawnione działają w sferze publicznej poprzez swoje organizacje. I tak, interesy branżowe są zwykle reprezentowane przez izby gospodarcze i stowarzyszenia sektorowe, których członkami są inne stowarzyszenia lub osoby fizyczne, albo też firmy, a także przez organizacje zbiorowego zarządzania prawami autorskimi pokrewnymi. Nie oznacza to jednak, że w sferze publicznej nie można zaobserwować aktywności pojedynczych podmiotów gospodarczych. Jeśli chodzi o interesy użytkowników, zwykle są one reprezentowane przez takie organizacje pozarządowe, jak stowarzyszenia, fundacje, a także think-tanki (w zakresie interesów rozproszonych) oraz instytucje i organizacje kultury, które działają samodzielnie bądź pod egidą swoich organizacji parasolowych.

Analiza reprezentacji interesów w obszarze prawa autorskiego skłania do stwierdzenia, że charakteryzuje się ona pewną asymetrią, jeśli chodzi o liczbę występujących podmiotów (Vetulani-Cęgiel, 2014). Otóż w obszarze tym działa dużo więcej 
organizacji grup interesu, które reprezentują podmioty uprawnione z tytułu praw autorskich lub pokrewnych (twórcy, artyści, producenci branży muzycznej i audiowizualnej itd.) w stosunku do tych, które reprezentują interesy użytkowników chronionych treści. Zaistniałą nierówność w reprezentacji interesów (na korzyść podmiotów uprawnionych) pogłębia różnica w rodzaju organizacji reprezentujących interesy podmiotów uprawnionych oraz użytkowników. Podczas gdy interesy tych pierwszych są reprezentowane przez organizacje branżowe/sektorowe, które lobbują za konkretnymi przepisami prawno-autorskimi, w imieniu interesów użytkowników występują organizacje o szerszym profilu działania (organizacje pozarządowe broniące interesu publicznego lub interesów rozproszonych albo organizacje strażnicze), dla których regulacje prawno-autorskie są jednym z wielu obszarów działań.

\section{Strategie w obszarze reprezentacji interesów ${ }^{10}$}

\section{Uwagi ogólne}

Z uwagi na fakt, że poszczególne typy grup i kategorii interesów (biznesowe, zawodowe, obywatelskie) są dobrze opisane w literaturze, wiadomo, iż mają one różne preferencje w obieraniu strategii działań. Niektórzy badacze twierdzą, że typ grupy nie przekłada się na skuteczność działań lobbingowych (Klüver, 2012), a inni zwracają uwagę na zależność wyboru strategii od typu grup lub typu interesów (biznesowe/pozarządowe). Badania dotyczą zarówno strategii bezpośrednich i pośrednich (Binderkrantz, 2008; Dür, Mateo, 2013), jak i działań kolektywnych. Jeśli chodzi o te ostatnie, analizuje się preferencje grup w zakresie powoływania organizacji lub innych działań wspólnych (De Bruycker i in., 2019), tworzenia różnego rodzaju koalicji (Klüver, 2011; Junk, 2019) czy sieci powiązań (Haunss, Kohlmorgen, 2010; Heaney, 2014).

Jedną ze strategii lobbingowych jest udział w konsultacjach, zarówno o charakterze inkluzywnym (internetowe konsultacje publiczne) (Quittkat, 2011), jak i ekskluzywnym/deliberacyjnym (grupy eksperckie, grupy robocze, wysłuchania). Zwłaszcza te ostatnie cieszą się dużym zainteresowaniem interesariuszy (Quittkat, Kotzian, 2011: 412). Warto zauważyć, że w niektórych przypadkach strategie lobbingowe są wprost nakierowane na otwarcie przez ustawodawcę tego rodzaju konsultacji

10 Dane zawarte w tym artykule stanowią część analizy przedstawionej w przyjętej do druku monografii A. Vetulani-Cęgiel, Polski lobbing w obszarze prawa autorskiego na tle systemu unijnego. 
(Vetulani-Cęgiel, 2014: 218-219), ponieważ już samo zapewnienie sobie w nich udziału jest kluczowe dla skuteczności lobbingowej.

W Polsce średnia liczba podmiotów uczestniczących w konsultacjach inkluzywnych, otwieranych w latach 2013-2018 w badanym obszarze, utrzymywała się na poziomie 38 uczestników ${ }^{11}$. Łącznie w konsultacjach wzięło udział 147 podmiotów, jednak tylko nieco ponad $1 / 3$ z nich (dokładnie 58) uczestniczyła w więcej niż w jednej konsultacji. W tej grupie 39 reprezentowało interesy podmiotów, 17 - użytkowników (instytucji kultury oraz obywateli) i 1 - środowisko akademickie. Fakt ten potwierdza asymetrię interesów wśród aktywnych uczestników polskich procesów konsultacyjnych. $Z$ badań wynika ponadto, że najbardziej zaangażowane w procesy konsultacyjne były organizacje zbiorowego zarządzania prawami podmiotów uprawnionych.

Badania nad partycypacją interesariuszy w konsultacjach dotyczących prawa autorskiego pozwoliły na wyodrębnienie kilku typów strategii działań kolektywnych, które uwzględniają logikę członkostwa oraz usieciowienie środowiska. W dalszej części pracy skoncentrujemy się na takich kierunkach działań, jak zwiększanie reprezentatywności, podejmowanie aktywności zrzeszeniowej, strategie w procesie konsultacji oraz powiązania personalne.

\section{Członkostwo w organizacjach}

\section{Zwiększanie reprezentatywności}

Organizacje grup interesu, niezależnie od własnej struktury (zrzeszeniowej lub nie), w celu (jeszcze) lepszej reprezentacji interesów swojego środowiska, powołują nierzadko własne organizacje, tzw. organizacje parasolowe. Uważa się, że im większa jest liczba członków (stowarzyszeń i/lub pojedynczych podmiotów) w danej organizacji parasolowej, tym większą posiada ona reprezentatywność względem ustawodawcy (dlatego też, chcąc wzmocnić swoją pozycję względem innych podmiotów, grupy parasolowe dążą do reprezentowania znaczącej liczby aktorów). Podmioty o szerokim, międzysektorowym zakresie działań są zatem bardziej reprezentatywne od organizacji parasolowych, działających w obrębie jakiejś specyficznej branży.

11 W jednym tylko przypadku liczba uczestników przekroczyła 100. Z uwagi na wyjątkowo szeroką partycypację, wynikającą z zakresu przedmiotowego planowanej regulacji, liczba ta nie została wliczona do średniej. 
Jeśli jednak spojrzeć na reprezentatywność konkretnych podmiotów przez pryzmat prowadzonych konsultacji publicznych $\mathrm{w}$ danym obszarze, to kwestia reprezentatywności danej organizacji staje się względna. W perspektywie sektorowej dysproporcje między różnymi organizacjami parasolowymi nie zawsze są widoczne, ponieważ te duże, międzysektorowe, i tak reprezentują w danych konsultacjach obszarowych tylko interesy konkretnych (zainteresowanych) środowisk. Ponadto zdarza się, że organizacje o zbyt szerokim profilu działania nie uczestniczą w sektorowych konsultacjach, mimo iż mają dużą reprezentatywność w swoim sektorze. Dzieje się tak, gdy nie zdołają wypracować konsensusu wśród swoich członków.

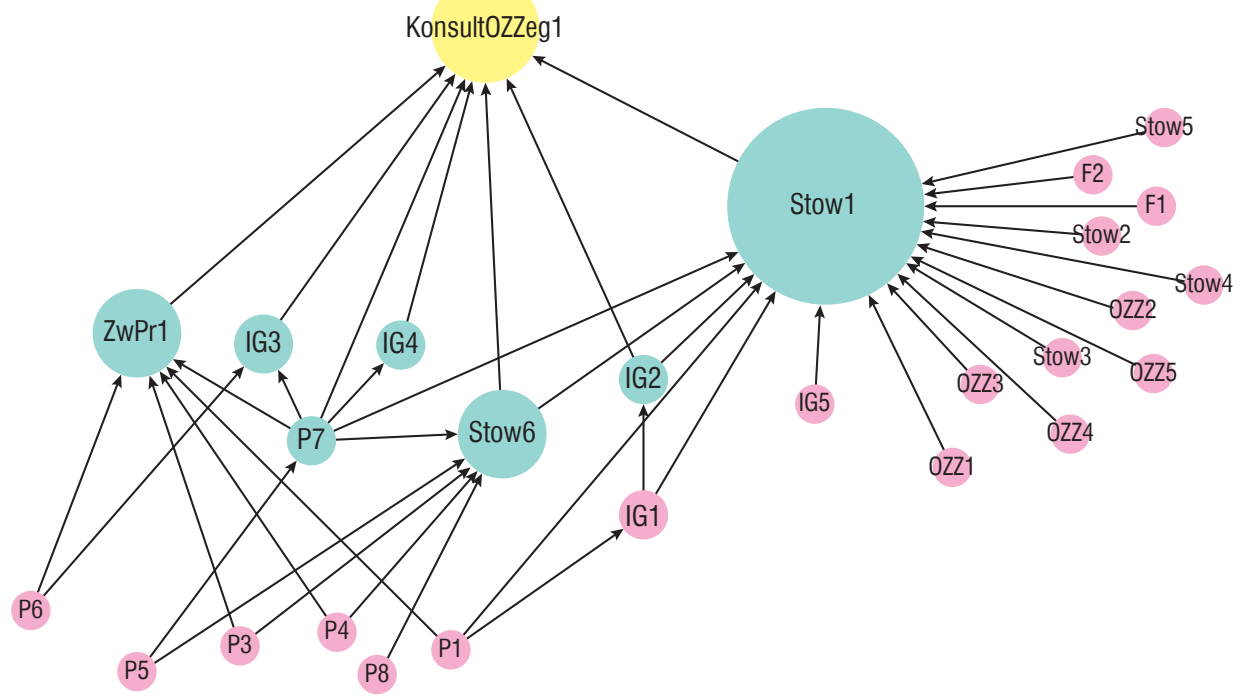

\section{Rysunek 1. Reprezentatywność organizacji względem ustawodawcy}

Stow - stowarzyszenie, IG - izba gospodarcza, OZZ - organizacja zbiorowego zarządzania, P - podmiot gospodarczy, ZwPr - związek pracodawców, F - fundacja

Źródło: opracowanie własne.

Mimo powyższych uwag analiza udziału organizacji w konsultacjach publicznych pokazuje, że pewne organizacje okazują się bardziej reprezentatywne od innych. Rysunek 1 przedstawia schemat odzwierciedlający reprezentatywność organizacji względem ustawodawcy polskiego podczas konsultacji w sprawie Projektu ustawy o zbiorowym zarządzaniu prawami autorskimi i prawami pokrewnymi ${ }^{12}$, pozwalający zaobserwować, które z organizacji parasolowych, biorących udział w konsultacjach, reprezentują interesy większej liczby podmiotów i tym samym, które z nich

12 Dostęp do procesu konsultacji: https://legislacja.rcl.gov.pl/projekt/12297411. 
są bardziej reprezentatywne dla ustawodawcy (większe węzły). Reprezentatywność dotyczy podmiotów, które biorą bezpośrednio udział w konsultacjach i jednocześnie reprezentują interesy swoich członków (podmioty oznaczone kolorem niebieskim).

Rysunek potwierdza dysproporcje $\mathrm{w}$ zakresie reprezentatywności pomiędzy poszczególnymi organizacjami parasolowymi. Można zatem sądzić, że argumenty przedstawiane przez bardziej reprezentatywne podmioty będą bardziej przekonujące dla ustawodawcy od tych, które są zgłaszane przez pojedyncze podmioty lub grupy reprezentujące mniejszą liczbę aktorów w danym sektorze.

\section{Aktywność zrzeszeniowa}

Analizując aktywność podmiotów w sferze publicznej, łatwo dostrzec, że zabiegają one o reprezentację swoich interesów poprzez organizacje parasolowe. Dokładne przyjrzenie się ich przynależności pokazuje jednak, iż w wielu przypadkach są one członkami więcej niż jednej organizacji, co z kolei uprawnia do mówienia o dużej „aktywności zrzeszeniowej” podmiotu. Im większa jest przynależność podmiotu do różnych organizacji, tym szerzej reprezentowane są jego interesy.

Można wyróżnić dwa rodzaje aktywności zrzeszeniowej - poziomą i pionową. W przypadku tej pierwszej dany podmiot jest członkiem wielu różnych organizacji parasolowych. Tego typu przypadek odzwierciedla przykład przedstawiony na rysunku 2, który uwidacznia przynależność podmiotu P7 do aż pięciu organizacji parasolowych, podmiotu P1 do trzech organizacji, a pozostałych tylko do dwóch. Niewątpliwie interesy podmiotu P7 są reprezentowane w większym stopniu w stosunku do interesów pozostałych podmiotów tej branży.

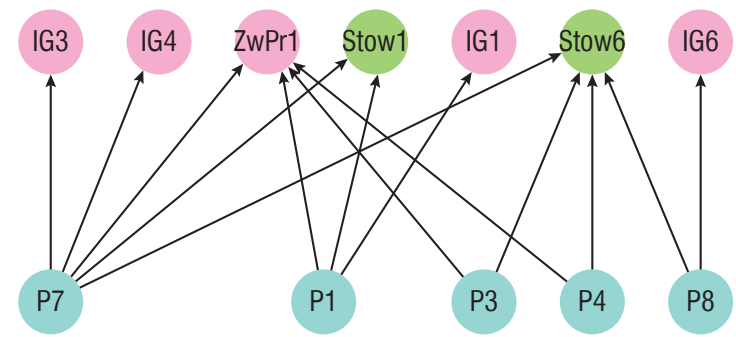

\section{Rysunek 2. Aktywność zrzeszeniowa (pozioma)}

Stow - stowarzyszenie, IG - izba gospodarcza, P - podmiot gospodarczy, ZwPr - związek pracodawców Źródło: opracowanie własne.

Z kolei aktywność zrzeszeniowa pionowa zachodzi w sytuacji, gdy dany podmiot przynależy do dwóch organizacji parasolowych i jednocześnie jedna z tych 
organizacji (parasolowych) jest członkiem tej drugiej. Okazuje się, iż nie są to przypadki odosobnione. Rysunek 3 ilustruje trzy przykłady tego typu.

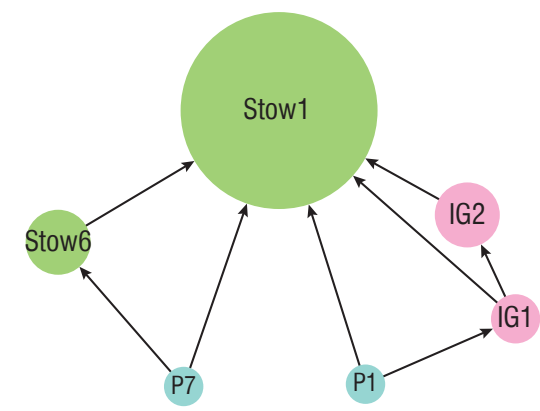

Rysunek 3. Aktywność zrzeszeniowa (pionowa)

Stow - stowarzyszenie, IG - izba gospodarcza, P - podmiot gospodarczy

Źródło: opracowanie własne.

Im większa jest aktywność zrzeszeniowa danego podmiotu, tym bardziej zintegrowane jest środowisko. Można także zauważyć, że interesy podmiotów bardziej aktywnych są powielane w przypadku członkostwa w wielu organizacjach parasolowych, co prowadzi do nadreprezentacji ich interesów.

\section{Działania w toku konsultacji}

Procesy konsultacyjne stanowią dobre pole obserwacji dla zrozumienia mechanizmów funkcjonujących podczas reprezentowania swoich stanowisk przez grupy interesów. Okazuje się, iż niektóre organizacje biorą udział w konsultacjach samodzielnie, niezależnie od tego, że w ich imieniu głos zabiera także organizacja parasolowa, której są członkiem, i w ramach której dochodzi do uzgadniania wspólnego stanowiska. Dobrym przykładem ilustrującym tego typu sytuację są konsultacje dotyczące zbiorowego zarządzania prawami autorskimi i pokrewnymi.

Rysunek 4 pokazuje, że podmioty, które należą do organizacji parasolowej (Stow1), i które jednocześnie partycypują w konsultacjach równolegle (niezależnie), są lepiej reprezentowane w stosunku do pozostałych grup, które są członkami tej samej organizacji parasolowej (Stow1), a które nie wysuwają stanowisk samodzielnie. Ten typ uczestnictwa można nazwać „bajpasowaniem” (omijaniem) organizacji parasolowych. Dodatkowo interesy tych podmiotów są też mocniej reprezentowane w stosunku do pozostałych organizacji biorących udział w konsultacjach, niezrzeszonych w organizacji Stow1. Taki stan rzeczy prowadzi również do nadreprezentacji 
ich interesów (na rysunku 4 większe węzły odpowiadają podmiotom, które silniej reprezentują swoje interesy).

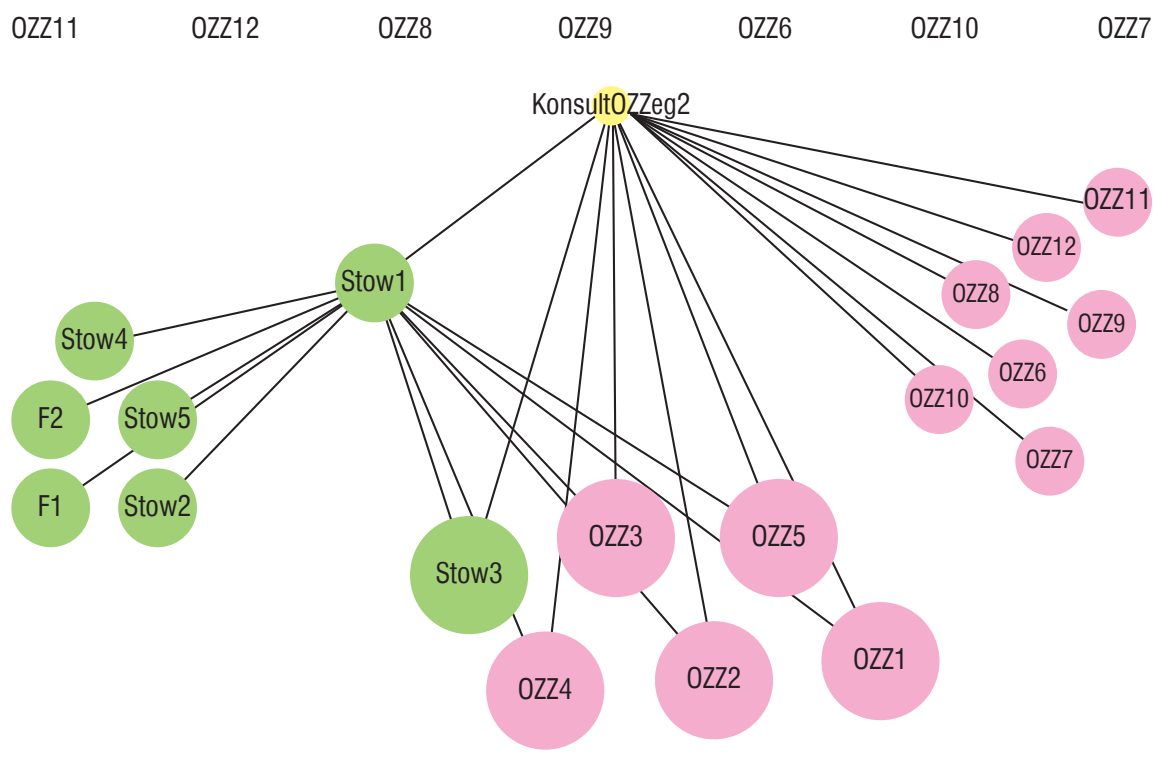

Rysunek 4. Bajpasowanie organizacji parasolowych w konsultacjach

Stow - stowarzyszenie, F - fundacja, OZZ - organizacja zbiorowego zarządzania Źródło: opracowanie własne.

\section{Powiązania personalne}

Jak już zostało powiedziane, organizacje parasolowe reprezentują interesy swoich organizacji członkowskich względem ustawodawcy. Członkostwo w organizacjach o szerszym zasięgu (stowarzyszenia, izby gospodarcze) świadczy też o istnieniu zależności między poszczególnymi podmiotami w zakresie formalnej reprezentacji interesów. Sam fakt członkostwa nie ukazuje jednak faktycznych relacji, jakie zachodzą pomiędzy poszczególnymi podmiotami. Aby lepiej zobrazować to zjawisko, należy jeszcze uwzględnić powiązania personalne. Mamy tu na myśli powiązania wynikające z funkcji pełnionych formalnie przez przedstawicieli różnych podmiotów/organizacji w organach innych organizacji (np. zasiadanie w zarządzie, komisjach rewizyjnych, sądach koleżeńskich itp.). Poniżej, tytułem przykładu, przedstawiamy trzy schematy odzwierciedlające zależności, które występują pomiędzy interesariuszami branży kreatywnej, i które wynikają z: członkostwa w organizacjach (linie kierunkowe 
- rysunek 5), powiązań personalnych (linie czerwone - rysunek 6) oraz jednocześnie z powiązań personalnych i członkostwa (rysunek 7).

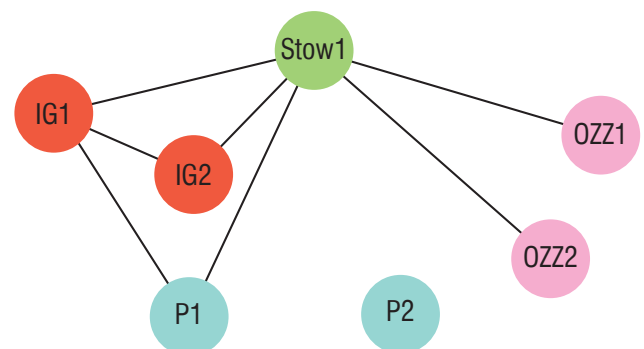

\section{Rysunek 5. Członkostwo w organizacjach parasolowych}

Stow - stowarzyszenie, IG - izba gospodarcza, OZZ - organizacja zbiorowego zarządzania, P - podmiot gospodarczy

Źródło: opracowanie własne.

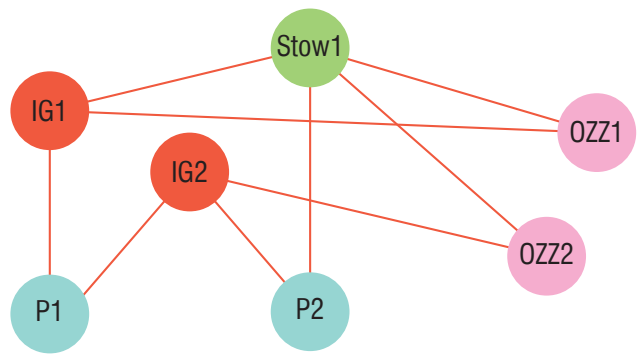

\section{Rysunek 6. Powiązania personalne między podmiotami}

Stow - stowarzyszenie, IG - izba gospodarcza, OZZ - organizacja zbiorowego zarządzania, P - podmiot gospodarczy

Źródło: opracowanie własne.

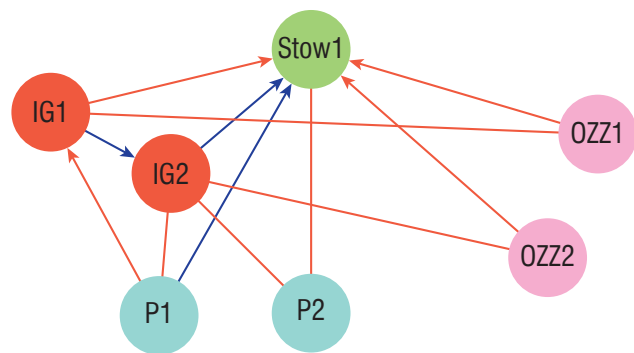

\section{Rysunek 7. Powiązania personalne i zależności wynikające z członkostwa}

Stow - stowarzyszenie, IG - izba gospodarcza, OZZ - organizacja zbiorowego zarządzania, P - podmiot gospodarczy

Źródło: opracowanie własne. 
Jeśli uwzględni się powiązania personalne pomiędzy poszczególnymi podmiotami, działającymi w ramach jednej branży, to okazuje się, że stopień zintegrowania środowiska jest znacznie większy. De facto reprezentowanie interesów określonego środowiska poszerza się o inne podmioty, ponieważ organizacje parasolowe, wyrażając jakąś opinię, przedstawiają nie tylko interesy swoich formalnych członków, ale także (częściowo) innych podmiotów, które zasiadają w ich strukturach.

Analiza partycypacji interesariuszy w konsultacjach publicznych dotyczących przepisów prawa autorskiego pozwala na spojrzenie na kwestię reprezentacji interesów w ujęciu dynamicznym, tzn. jako na strategię lobbingową prowadzoną w celu poprawy skuteczności działań podczas zabiegania o ochronę interesów. Zidentyfikowane strategie dotyczące zachowań kolektywnych (w kontekście członkostwa w organizacjach, udziału w procesie konsultacji i powiązań personalnych) świadczą, z jednej strony, o dużym zintegrowaniu środowiska, a z drugiej, o pewnej „nadreprezentacji” interesów niektórych grup.

Nadreprezentacja interesów to z pewnością jeden z czynników, który odgrywa dużą rolę w działalności grup lobbingowych. Między innymi w ten sposób grupy dążą do osiągnięcia sukcesu. Chociaż inkluzywny charakter konsultacji publicznych daje szansę na udział wszystkim zainteresowanym stronom, to nadmierna reprezentacja interesów pewnych aktorów skutkuje niekiedy fałszywą oceną potrzeb społecznych przez ustawodawcę, gdyż głos środowisk nadreprezentowanych jest po prostu bardziej słyszalny. Ryzyko jest tym większe, im większa jest asymetryczność układu interesów. Dlatego też niepożądana jest niska frekwencja jakichś podmiotów w konsultacjach, zwłaszcza gdy reprezentują one interesy grup słabszych (np. interesy rozproszone). Przy słabej reprezentacji jakiejś strony zwiększa się ryzyko zawłaszczenia regulacji przez grupy bardziej aktywne i silniej zabiegające o reprezentację własnych interesów.

W celu zapobiegania wyżej opisanym, niekorzystnym, zjawiskom stosuje się odpowiednie zarządzanie regulacyjne strukturyzujące partycypację interesariuszy w ramach procesów kształtowania polityki publicznej. Przykładem tego typu rozwiązań są unijne procedury konsultacji, które wymuszają dążenie do osiągnięcia zrównoważonej reprezentacji interesów. W szczególności kładzie się nacisk na: widoczność konsultacji, szeroką partycypację, a także dywersyfikację metod konsultacyjnych oraz skrupulatną identyfikację interesariuszy. Polski ustawodawca nie rozwiązuje (jeszcze) problemów w tym zakresie. Do mankamentów szczególnie widocznych należą m.in.: brak dobrych metod rozpowszechniania informacji o konsultacjach (brak efektywnych mechanizmów internetowych) i stosowanie rozdzielnika, krótki czas przeznaczony na przesyłanie kontrybucji, nieefektywny mechanizm rejestrów 
lobbingowych (nieuwzględnianie lobbingu prowadzonego przez podmioty grupowe), a także obowiązek przeprowadzania konsultacji jedynie w przypadku rządowych projektów aktów prawnych. Brak kontrolnych mechanizmów w procedurach regulujących reprezentację interesów w konsultacjach stwarza ryzyko uzyskiwania skrzywionych wyników konsultacji z uwagi na nieuwzględnianie interesów stron nieobecnych. Sytuacje tego typu mogą w rezultacie prowadzić do przyjmowania niewyważonych mechanizmów prawnych.

Konkludując, podejmowane przez interesariuszy aktywne działania w zakresie wzmacniania reprezentacji swoich interesów oprócz tego, że prowadzą do integracji środowiska, przyczyniają się do „nadreprezentacji” interesów pewnych stron. Tym samym wydaje się, iż przyjęte na wstępie pracy założenia mogą być potwierdzone. Przy braku odpowiednich mechanizmów zarządzania regulacyjnego zwiększa się ryzyko „zawłaszczania regulacji” przez podmioty wpływowe, a istniejące w Polsce mechanizmy instytucjonalne nie pozwalają na zminimalizowanie ryzyka wystąpienia tego negatywnego zjawiska.

\section{Bibliografia}

Antoszewski, A. (2003). Grupy interesu w systemie politycznym, w: Grupy interesu. Teorie i działanie, Machelski Z., Rubisz L. (red.). Toruń: Wydawnictwo Adam Marszałek.

Binderkrantz, A. (2008). Different Groups, Different Strategies: How Interest Groups Pursue Their Political Ambitions. Scandinavian Political Studies 31(2): 173-200, http://doi.wiley. com/10.1111/j.1467-9477.2008.00201.x

Bouwen, P. (2002). Corporate lobbying in the European Union: The logic of access. Journal of European Public Policy 9(3): 365-390.

Cianciara, A.K. (2018). Hasło: Parlamentarne wysłuchanie publiczne, w: Leksykon lobbingu w UE, Czub J.F., Vetulani-Cęgiel A. (red.). Warszawa: Dom Wydawniczy Elipsa.

Crespy, A. (2014). Deliberative Democracy and the Legitimacy of the European Union: A Reappraisal of Conflict. Political Studies 62 (1_suppl): 81-98, http://journals.sagepub. com/doi/10.1111/1467-9248.12058

De Bruycker, I., Berkhout, J., Hanegraaff, M. (2019). The paradox of collective action: Linking interest aggregation and interest articulation in EU legislative lobbying. Governance 32(2): 295-312, https://onlinelibrary.wiley.com/doi/abs/10.1111/gove.12373

Dür, A., Mateo, G. (2013). Gaining access or going public? Interest group strategies in five European countries. European Journal of Political Research 52(5): 660-686, http://doi. wiley.com/10.1111/1475-6765.12012

Dür, A., Mateo, G. (2014). Public opinion and interest group influence: how citizen groups derailed the Anti-Counterfeiting Trade Agreement. Journal of European Public Policy 21(8): 1199-1217, http://www.tandfonline.com/doi/full/10.1080/13501763.2014.900893 
European Commission (2015). Better Regulation Guidelines, Commission Staff Working Document, Strasbourg, 19.5.2015, SWD (2015) 111 final, COM(2015) 215 final SWD (2015) 110 final.

Farrand, B. (2014). Networks of power in digital copyright law and policy: Political salience, expertise and the legislative process. Abingdon, OX: Routledge.

Ferfecki, W. (2018, February 21). W Sejmie nie ma już lobbystów. Rzeczpospolita, https://www. rp.pl/Polityka/302219907-W-Sejmie-juz-nie-ma-lobbystow.html

Gendreau, Y. (2013). Balancing the Balance. IIC-International Review of Intellectual Property and Competition Law 44(6): 623-625, http://link.springer.com/10.1007/s40319-013-0091-9

Gornitzka, A., Holst, C. (2015). The Expert-Executive Nexus in the EU: An Introduction. Politics and Governance 3(1): 1, http://www.cogitatiopress.com/ojs/index.php/politicsandgovernance/article/view/271

Haunss, S., Kohlmorgen, L. (2009). Lobbying or politics? Political claims making in IP conflicts. First publ. in: Politics of Intellectual Property, Haunss, S. (ed.) Cheltenham: Elgar: 107-128.

Haunss, S., Kohlmorgen, L. (2010). Conflicts about intellectual property claims: the role and function of collective action networks. Journal of European Public Policy 17(2): 242-262, http:// www.tandfonline.com/doi/abs/10.1080/13501760903561534

Heaney, M.T. (2014). Multiplex networks and interest group influence reputation: An exponential random graph model. Social Networks 36: 66-81, https://inkinghub.elsevier.com/ retrieve/pii/S0378873312000664

Herbut, R. (2003). Grupy interesu a proces decyzyjny, w: Grupy interesu. Teorie i działanie, Machelski Z., Rubisz L. (red.). Toruń: Wydawnictwo Adam Marszałek.

Hilty, R., Kur, A., Klass, N., Geiger, C., Peukert, A., Drexl, J., Katzenberger, P. (2008). Comment by the Max Planck Institute on the Commission's Proposal for a Directive to Amend Directive 2006/116 EC of the European Parliament and Council Concerning the Term of Protection for Copyright and Related Rights. SSRN Electronic Journal, http://www.ssrn. com/abstract $=1288620$

Horten, M. (2013). A copyright masquerade: how corporate lobbying threatens online freedoms. London, New York: Zed Books.

Jasiecki, K. (2000). Lobbing gospodarczy w Polsce. Studia Socjologiczne 159(4).

Jasiecki, K. (2015). Problemy partycypacji społecznej w Polsce i ich wpływ na politykę publiczną. Studia z Polityki Publicznej 3(7): 101-119.

Junk, W.M. (2019). When Diversity Works: The Effects of Coalition Composition on the Success of Lobbying Coalitions. American Journal of Political Science 63(3): 660-674, https:// onlinelibrary.wiley.com/doi/abs/10.1111/ajps.12437

Klüver, H. (2011). Lobbying in coalitions: Interest group influence on European Union policy-making. Nuffield's Working Papers Series in Politics: 1-38, https://www.nuffield.ox.ac.uk/ politics/papers/2011/Heike\%20Kluever_working\%20paper_2011_04.pdf

Klüver, H. (2012). Biasing Politics? Interest Group Participation in EU Policy-Making. West European Politics 35(5): 1114-1133. 
Kohler-Koch, B. (2010). Civil society and EU democracy: 'astroturf' representation?. Journal of European Public Policy 17(1): 100-116.

Kopka, A., Piontek, D., Minkenberg, M. (eds.) (2018). Doradztwo polityczne i lobbing w parlamentarnym procesie decyzyjnym. Polska i Niemcy w perspektywie porównawczej. Kraków, Nowy Targ: Wydawnictwo ToC.

Kurczewska, U. (red.) (2008). Deficyt demokracji w Unii Europejskiej a europejskie grupy interesów. Warszawa: Wydawnictwa Uniwersytetu Warszawskiego.

Littoz-Monnet, A. (2006). Copyright in the EU: droit d'auteur or right to copy? Journal of European Public Policy 13(3): 438-455, https://www.tandfonline.com/doi/full/10.1080/ 13501760600560516

Matthews, D., Žikovská, P. (2013). The Rise and Fall of the Anti-Counterfeiting Trade Agreement (ACTA): Lessons for the European Union. IIC-International Review of Intellectual Property and Competition Law 44(6): 626-655, https://doi.org/10.1007/s40319-013-0081-y

Meyer, T., Vetulani-Cęgiel, A. (2017). From ACTA to TTIP: Lessons Learned on Democratic Process and Balancing of Rights, w: Trans-Atlantic Data Privacy Relations as a Challenge for Democracy (Vol. 4), Svantesson D.J.B., Kloza D. (eds.). Cambridge, UK: Intersentia.

Obywatelskie Forum Legislacji (2019). Skrywane projekty ustaw, XII Komunikat Obywatelskiego Forum Legislacji o jakości procesu legislacyjnego na podstawie obserwacji prowadzonej $w$ okresie od 16 maja do 15 listopada 2018 roku oraz podsumowujący aktywność legislacyjna rządu i parlamentu w trzecim roku ich działalności. Warszawa: Fundacja im. Stefana Batorego, http://www.batory.org.pl/upload/files/Programy\%20operacyjne/Forum\%20Idei/ XII_Komunikat_OFL.pdf

Program Lepsze Regulacje 2015 (2013). Załącznik do uchwały nr 13/2013 Rady Ministrów z dnia 22 stycznia 2013 r. Ministerstwo Gospodarki.

Quittkat, C. (2011). The European Commission's Online Consultations: A Success Story? JCMS: Journal of Common Market Studies 49(3): 653-674, http://doi.wiley.com/10.1111/ j.1468-5965.2010.02147.x

Quittkat, C., Kotzian, P. (2011). Lobbying via Consultation - Territorial and Functional Interests in the Commission's Consultation Regime. Journal of European Integration 33(4): 401-418.

Rasmussen, M.K. (2015). The Battle for Influence: The Politics of Business Lobbying in the European Parliament: The battle for influence. JCMS: Journal of Common Market Studies 53(2): 365-382, http://doi.wiley.com/10.1111/jcms.12156

Reg. RM. (2013). Uchwała nr 190 Rady Ministrów z dn. 29.10.2013 r. - Regulamin pracy Rady Ministrów, ze zm., https://bip.kprm.gov.pl/kpr/bip-rady-ministrow/podstawy-prawne/2516, Regulamin-pracy-Rady-Ministrow.html

Saurugger, S. (2008). Interest Groups and Democracy in the European Union. West European Politics 31(6): 1274-1291.

Scharpf, F.W. (1999). Governing in Europe: effective and democratic?. Oxford, New York: Oxford University Press.

Ust. lobb. (2005). Ustawa z dnia 7 lipca 2005 r. o działalności lobbingowej w procesie stanowienia prawa, Dz. U. nr 169, poz. 1414. 
Vetulani-Cęgiel, A. (2014). Lobbing w procesie ksztattowania prawa autorskiego w Unii Europejskiej. Studium przypadków: czas trwania praw pokrewnych, dzieła osierocone, ACTA. Warszawa: Wolters Kluwer SA.

Vetulani-Cęgiel, A. (2015a). EU Copyright Law, Lobbying and Transparency of Policy-Making: The cases of sound recordings term extension and orphan works provisions. JIPITEC: Journal of Intellectual Property, Information Technology and E-Commerce Law 6(2): 146-162, https:// www.jipitec.eu/issues/jipitec-6-2-2015/4275

Vetulani-Cęgiel, A. (2015b). Kształtowanie unijnych regulacji prawnoautorskich. Problemy procesu konsultacyjnego i lobbingu grup interesu. Ruch Prawniczy, Ekonomiczny i Socjologiczny 77(2): 237, http://pressto.amu.edu.pl/index.php/rpeis/article/view/1199

Vetulani-Cęgiel, A. (2017). Nowe procedury konsultacji Komisji Europejskiej jako czynnik niwelujący deficyt demokracji w UE. Przeglad Europejski 45(3): 116-135, http://przegladeuropejski.wnpism.uw.edu.pl/zasoby/pliki/45/6-Vetulani.pdf

Wiaderek, G. (2015). Konsultacje z zasadami. Jakość konsultacji publicznych w procesach legislacyjnych. Opracowanie na temat szans i barier $w$ działaniach organizacji pozarzadowych $i$ administracji publicznej. Warszawa: Pracowania badań i innowacji społecznych Stocznia, https://partycypacjaobywatelska.pl/wp-content/uploads/2015/02/Grzegorz-Wiaderek-Jako\%C5\%9B\%C4\%87-konsultacji-publicznych_19.02.pdf

Wiszowaty, M.M. (2010). Działalność lobbingowa w procesie stanowienia prawa. Ustawa $z$ dnia 7 lipca 2005 r. z komentarzem. Warszawa: Wydawnictwo Sejmowe.

Yu, P.K. (2004). The Escalating Copyright Wars. Hofstra Law Review 32(3): 907-951, https:// scholarlycommons.law.hofstra.edu/hlr/vol32/iss $3 / 3$ 
Oficyna Wydawnicza SGH - Szkoła Główna Handlowa w Warszawie 02-554 Warszawa, al. Niepodległości 162

www.wydawnictwo.sgh.waw.pl

e-mail: wydawnictwo@sgh.waw.pl

Projekt okładki

Ad Depositum

Skład i łamanie

DM Quadro

Druk i oprawa

QUICK-DRUK s.c.

Zamówienie 78/VII/20 